\title{
THE MAMMALS OF COLORADO
}

Colorado Mammals. ${ }^{1}$ - About seven years ago I ealled on Mr. E. R. Warren at Colorado Springs, and saw his collection of mammals, then recently begun. It was a small affair, easily laid out on the parlor table. Since then, Mr. Warren has labored unceasingly, visiting many different parts of Colorado, and has accumulated an immense series of skins. The collection soon outgrew its original quarters, and is now housed in a special building, in numerous cabinets which are already overerowded. While mainly a Colorado collection, it includes many species from other parts of the country, obtained in exchange. Mr. Warren has not only collected all these materials for taxonomic investigations, but has paid much attention to the habits of the animals, and in particular has secured a splendid set of photographs showing them in their native haunts. The logical outcome of all this excellent work, a book on Colorado mammals, has just appeared. It contains descriptions of all the species and subspecies known to inhabit the state, with numerous illustrations, showing the living animals and the skull of each genus. It is so far technical that it contains exact descriptions and all other details needed for precise classification and identification, but each form is also discussed in a popular manner, often with entertaining anecdotes. Heretofore the study of Colorado mammals has seemed too difficult for any one not a specialist, but with the aid of this book it is made easy for any intelligent person, or as easy as such a subject, from its nature, can be. The only regret I have about the work is that there is not more of it: I should have liked a chapter on fossil mammals (especially of the later periods), and one on parasites of mammals.

Apart from my great pleasure in the book itself, I can not other than regard the manner of its production as a good omen. Mr. Warren has lately been appointed honorary curator of Colorado College Museum, but he is essentially an amateur, in the best sense of that word. He resembles the numerous amateur naturalists of England, who have done so much for science; like them, he has labored for the love of the work, without recompense, and has shouldered the expense of publication, heavy as it must have been. The most modest of men, I fear he may resent being called a benefactor, yet it would be hard to exaggerate the benefit to the community which might come from an increase of the spirit he represents. T. D. A. Cockerell.

1 ، The Mammals of Colorado," by E. R. Warren, G. P. Putnam's Sons, New York, 1910. 